\title{
Effects of curcumin or dexamethasone on lung ischaemia-reperfusion injury in rats
}

\author{
J. Sun*, D. Yang*, S. Li*, Z. Xü ${ }^{\#}$ X. Wang* and C. Bai*
}

ABSTRACT: The present study aimed to investigate potential effects of curcumin (CUR) and dexamethasone (DXM) on ischaemia-reperfusion (I/R) induced lung injury in rats.

Experimental rats were pre-treated with a single i.p. dose of vehicle, CUR (50 mg kg ${ }^{-1}$ or $200 \mathrm{mg} \cdot \mathrm{kg}^{-1}$ ) or DXM (5 mg $\left.\mathrm{kg}^{-1}\right), 2 \mathrm{~h}$ before anaesthesia and subjected to left lung hilus clamping with $90-\mathrm{min}$ ischaemia followed by $4 \mathrm{~h}$ of reperfusion.

Pre-treatment with CUR $\left(200 \mathrm{mg} \cdot \mathrm{kg}^{-1}\right)$ or DXM markedly attenuated I/R-induced barrier disruption, lung oedema, tissue inflammation, hypoxaemia $4 \mathrm{~h}$ after reperfusion, and overactivation of nuclear factor-кB, inflammatory cytokines, myeloperoxidase and malondialdehyde.

It appears that curcumin attenuates acute lung injury, probably through improving oxidative stress and inhibiting nuclear factor-кB-mediated expression of inflammatory cytokines. Thus, curcumin may be an alternative therapy for improving the outcomes of ischaemia-reperfusioninduced lung injury.

KEYWORDS: Curcumin, ischaemia-reperfusion, lung, microvascular permeability, nuclear factor- $\mathrm{B}$, oxidative stress

l schaemia-reperfusion (I/R)-associated acute lung injury (ALI) occurs in many clinical situations such as lung transplantation and becomes life-threatening in $\sim 20 \%$ of transplants, resulting in the primary dysfunction of implanted lungs and a mortality rate of $60 \%[1,2]$. Such compromise usually appears in the early stages of lung transplantation, characterised by nonspecific alveolar damage, lung oedema and hypoxaemia, as reported in clinical studies [3]. It is important to elucidate the molecular mechanisms of I/R-ALI in order to develop an effective therapeutic strategy. For instance, the redox-sensitive transcription factor nuclear factor $(\mathrm{NF})-\kappa \mathrm{B}$, which regulates genes encoding proinflammatory mediators, plays a pivotal role in the development of $I / R$ injury. The inhibition of NF- $\kappa \mathrm{B}$ activation could attenuate I/R-induced tissue injury [4, 5].

Curcumin (CUR), an active component of the rhizome Curcuma longa, shows wide anti-inflammatory, antioxidant and bactericidal effects [6, 7]. CUR downregulates the production of tumour necrosis factor (TNF)- $\alpha$ and interleukin (IL)- 1 and inhibits the activation of $N F-\kappa B$ and activator protein-1 [7]. Dexamethasone (DXM) modulates enzyme systems and inhibits the formation of cytokines, arachidonic acid products and NF- $\mathrm{KB}$ activation $[8,9]$. Pre-treatment with CUR or DXM has been suggested to reduce I/R-induced injury in multiple organs and tissues [10-14]. It was proposed that CUR and others might have a similar mechanism to glucocorticoids in the treatment of I/R injury [13]. The present study aimed to investigate the effects of CUR or DXM on alveolar-capillary membrane disruption, lung oedema, neutrophil lung tissue infiltration and hypoxaemia in a rat model of I/R-ALI.

\section{MATERIALS AND METHODS}

\section{Animals and surgical preparation}

Male Sprague-Dawley rats (Animal Center, Fudan University, Shanghai, China) weighing between 250-300 g, were used. The animals had no access to solid food but free access to water $12 \mathrm{~h}$ before the experiments. The experimental protocol was approved by the Committee of Animal Care (Fudan University). All animals were handled in accordance with the Guide for the Care and Use of Laboratory Animals [15]. Modified operations were performed as described previously [16]. Animals were anaesthetised by an i.p. injection of pentobarbital sodium at $50 \mathrm{mg} \cdot \mathrm{kg}^{-1}$ and i.m. injection of atropine at $0.2 \mathrm{mg}$. After cannulation, rats were mechanically ventilated (Harvard Rodent Ventilator Model 683; Harvard Apparatus, South Natick, MA, USA) with a standardised inspiratory oxygen fraction $\left(\mathrm{F}, \mathrm{O}_{2}\right)$ of $60 \%$ at a rate of 75 breaths $\mathrm{min}^{-1}$, a tidal volume at $10 \mathrm{~mL} \cdot \mathrm{kg}^{-1}$, positive end-expiratory pressure at $2 \mathrm{cmH}_{2} \mathrm{O}$ and arterial partial pressure of carbon dioxide $\left(\mathrm{Pa}_{\mathrm{a}} \mathrm{CO}_{2}\right)$ at $30-45 \mathrm{mmHg}$. A 22-gauge
AFFILIATIONS

*Dept of Pulmonary Medicine,

Zhongshan Hospital, Fudan

University, and

\# Dept of Pathology, Fudan

University, Shanghai, China.

CORRESPONDENCE

C. Bai

Dept of Pulmonary Medicine

Zhongshan Hospital

Fudan University

180 Feng Lin Road

Shanghai

200032

China

Fax: 862154961729

E-mail: bai.chunxue@

zs-hospital.sh.cn

Received:

October 282007

Accepted after revision:

August 292008

SUPPORT STATEMENT

The present study was supported by grant B115 from the Shanghai

Leading Academic Discipline Project

(Shanghai, China).

STATEMENT OF INTEREST

None declared.

European Respiratory Journal

Print ISSN 0903-1936

Online ISSN 1399-3003 
cannula inserted into the right carotid artery was used to monitor arterial blood gases (ABG) and draw blood samples. The animals were placed on their right sides, and a left anterolateral thoracotomy in the fifth intercostal space was performed. The left lung was mobilised atraumatically and the inferior pulmonary ligament was divided sharply. At this point, all animals received $50 \mathrm{U}$ of heparin i.v. After blood was harvested from the right carotid artery (CA) for ABG of preischaemia, the pulmonary hilum was occluded with a noncrushing microvascular clamp, including the left main bronchus, artery and vein, for $90 \mathrm{~min}$. After 90-min left-lung ischaemia, the clamp was removed and the lung was ventilated and reperfused for $4 \mathrm{~h}$. At the end of the reperfusion period, ABG were measured from CA and left pulmonary vein (LPV), and the $\mathrm{Pa}, \mathrm{O}_{2} / \mathrm{FI}_{1} \mathrm{O}_{2}$ value was compared with the pre-ischaemia value. Lung tissues were harvested for further analysis after the experiment was terminated. Surgery and tissue analyses were performed blindly.

\section{Experimental groups}

Animals were divided randomly into six experimental groups ( $\mathrm{n}=12$ animals per group): naïve animals (control); animals undergoing a sham operation and pre-treated with vehicle (sham); or animals with I/R-ALI and pre-treated with either vehicle, CUR at $50 \mathrm{mg} \cdot \mathrm{kg}^{-1}, \mathrm{CUR}$ at $200 \mathrm{mg} \cdot \mathrm{kg}^{-1}$ or DXM at $5 \mathrm{mg} \cdot \mathrm{kg}^{-1}$. Of these, 36 animals were used for measurement of lung microvascular permeability and 36 for the lung function and biochemical assays, in order to avoid contamination with Evans blue dye (EBD). CUR (Sigma-Aldrich Co., St. Louis, MO, USA) dissolved in dimethyl sulphoxide (DMSO) and DXM (Tianjin Pharmaceutical Co., Tianjin, China) in physiological saline were administered i.p. $2 \mathrm{~h}$ prior to $\mathrm{I} / \mathrm{R}$ induction. The doses of CUR and DXM used in the present study were based on previous experiments $[10,14]$ and the current authors' preliminary studies. In pilot studies, CUR dose ranges of 25 $400 \mathrm{mg} \cdot \mathrm{kg}^{-1}$ were tested; a dose of $200 \mathrm{mg} \cdot \mathrm{kg}^{-1}$ showed significant inhibitory effects on I/R-induced changes in vascular permeability and CUR treatment at $200 \mathrm{mg} \cdot \mathrm{kg}^{-1} 2 \mathrm{~h}$ prior to anaesthesia was more effective than treatment after the induction of ischaemia (data not shown). Doses of 50 and $200 \mathrm{mg} \cdot \mathrm{kg}^{-1}$ CUR were used in the current experiments.

\section{Lung tissue oedema and morphology}

The left lungs were harvested for measurements of lung tissue oedema by lung wet/dry weight ratio and morphology by staining with haematoxylin and eosin. All microscopic sections were interpreted, blinded, by a pulmonary pathologist. Lung neutrophil sequestration was measured by counting lung tissue neutrophils and was expressed as the number of neutrophils per 10 high-power fields of lung tissue, as described previously [17].

\section{Lung microvascular permeability}

Plasma leakage was measured using the EBD method, with minor modifications [18]. Animals received $30 \mathrm{mg} \cdot \mathrm{kg}^{-1}$ dye i.v. $30 \mathrm{~min}$ before the end of the reperfusion period. After the reperfusion period, median sternotomy was performed and heparin (500 units) was infused into abdominal aorta. An 18gauge cannula was inserted into the main pulmonary artery. The left atrial appendage and left ventricle were incised to allow free flow of effluent blood from the lung. The pulmonary vasculature was flushed with $50 \mathrm{~mL}$ of physiological saline at $20 \mathrm{cmH}_{2} \mathrm{O}$. After the dried tissues were immersed in $3 \mathrm{~mL}$ formamide and homogenised, the homogenate was incubated at $37^{\circ} \mathrm{C}$ for $24 \mathrm{~h}$ and centrifuged at 5,000 $\mathrm{g}$ for $30 \mathrm{~min}$. The optical density of the supernatant was measured by spectrophotometry at $620 \mathrm{~nm}$. For qualitative examination, lungs were sectioned into $10-\mu \mathrm{m}$ slices and examined by fluoromicroscopy.

\section{Myeloperoxidase activity and oxidative stress assay}

The left lung was used to determine pulmonary tissue myeloperoxidase (MPO) activity. Tissue MPO activity was measured to quantify polymorphonuclear leukocyte accumulation in the lungs [19]. The supernatant from lung homogenising
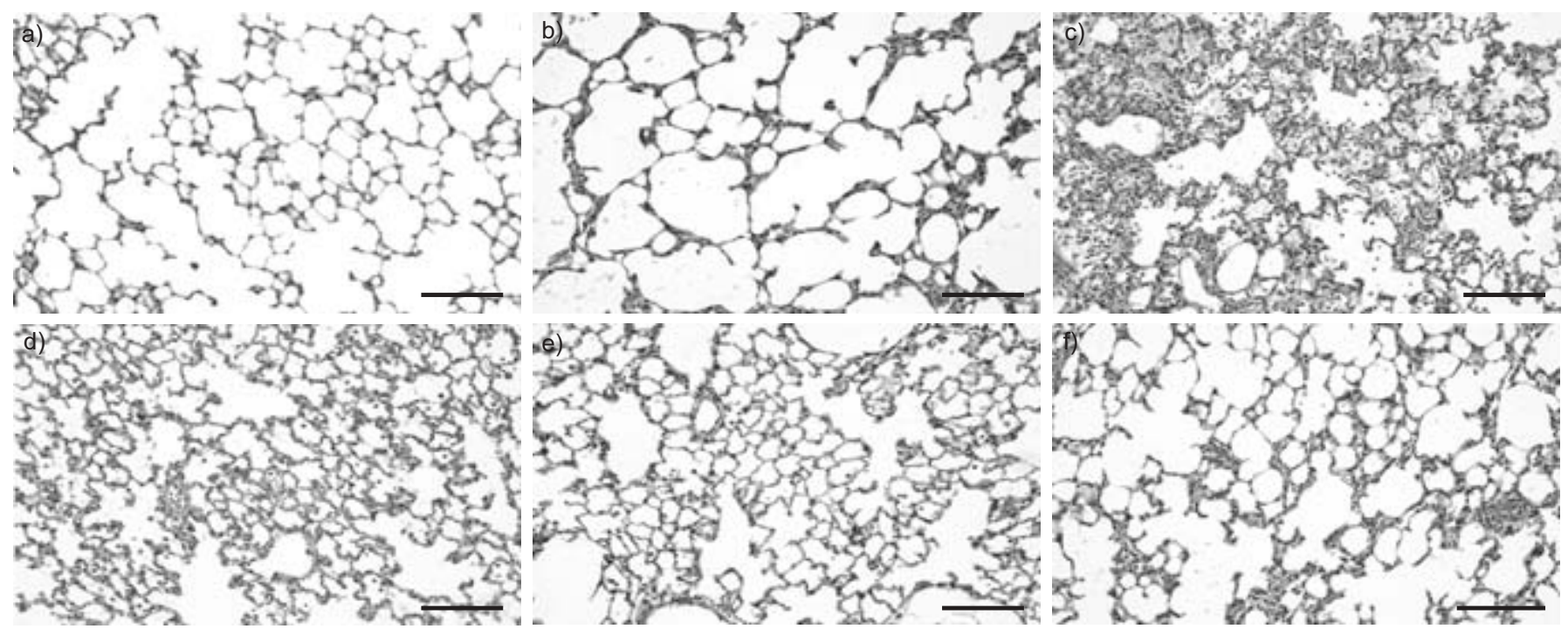

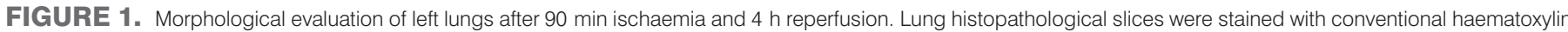

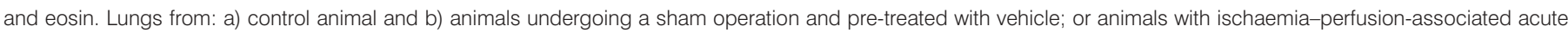
lung injury and pre-treated with c) vehicle, d) curcumin at $\left.50 \mathrm{mg} \cdot \mathrm{kg}^{-1}, \mathrm{e}\right)$ curcumin at $200 \mathrm{mg} \cdot \mathrm{kg}^{-1}$, or f) dexamethasone at $5 \mathrm{mg} \cdot \mathrm{kg}^{-1}$. Scale bars $=50 \mu \mathrm{m}$. 


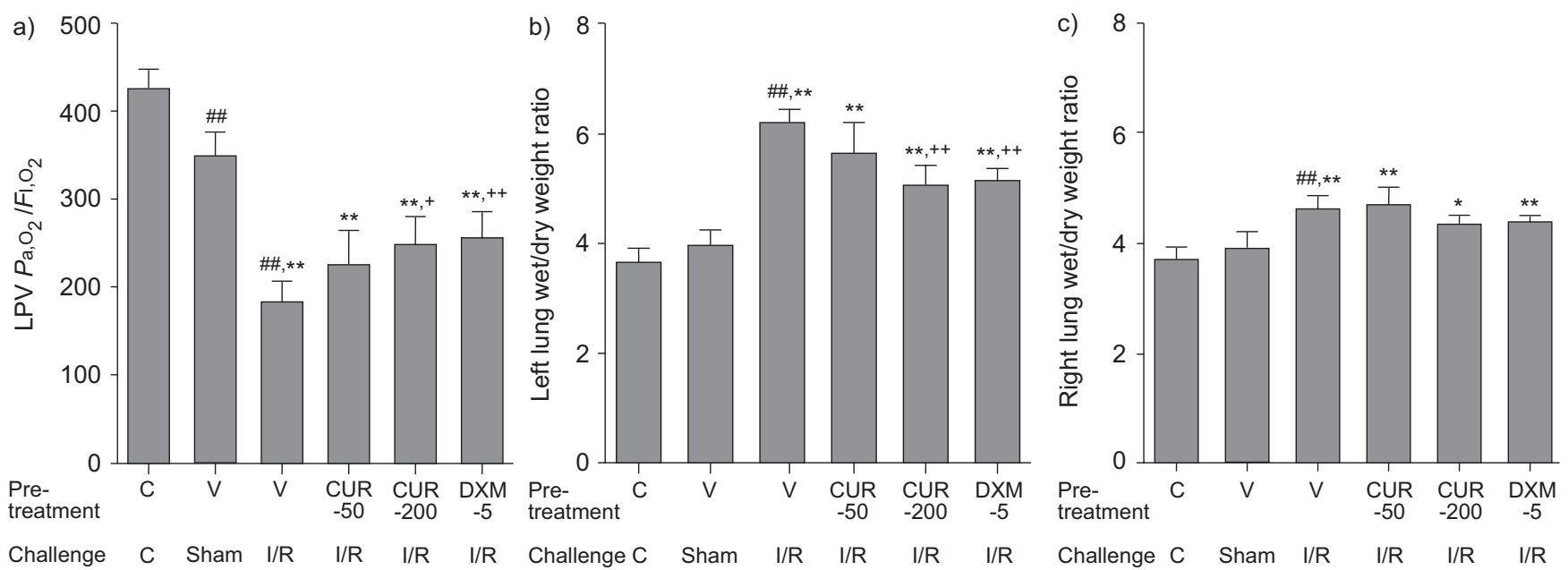

FIGURE 2. The a) arterial oxygen tension/inspired oxygen concentration $\left(\mathrm{Pa}_{1} \mathrm{O}_{2} / \mathrm{Fl}_{1} \mathrm{O}_{2}\right)$ ratio in the left pulmonary vein $(\mathrm{LPV})$ and lung wet/dry weight ratio of b) the left lungs and c) the right lungs of control (C) and experimental animals. CUR-50: pre-treatment with $50 \mathrm{mg} \cdot \mathrm{kg}^{-1}$ curcumin; CUR-200: pre-treatment with $200 \mathrm{mg} \cdot \mathrm{kg}^{-1} \mathrm{curcumin}$; DXM-5 pre-treatment with $5 \mathrm{mg} \cdot \mathrm{kg}^{-1}$ dexamethasone; $\mathrm{V}$ : vehicle; Sham: sham operation; I/R: ischaemia-reperfusion. ${ }^{*}: \mathrm{p}<0.05$ versus sham operation group; ${ }^{* *}$ : $p<0.01$ versus sham operation group; ${ }^{\# \#}: p<0.01$ versus control group; and ${ }^{+}: p<0.05$ versus I/R-associated acute lung injury (ALI); ${ }^{++}: p<0.01$ versus I/R-associated ALI.

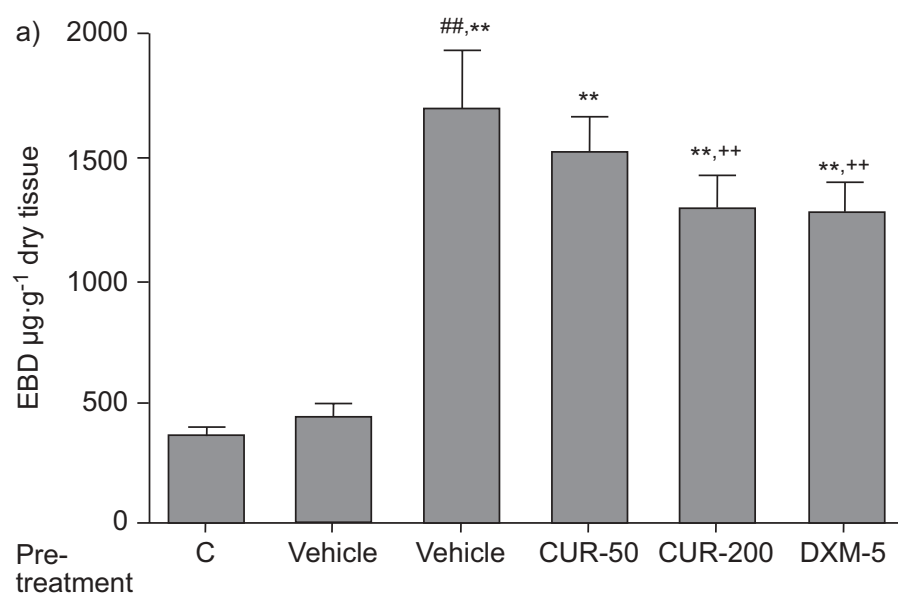

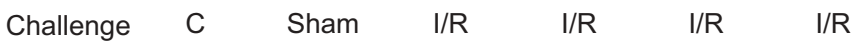

b)

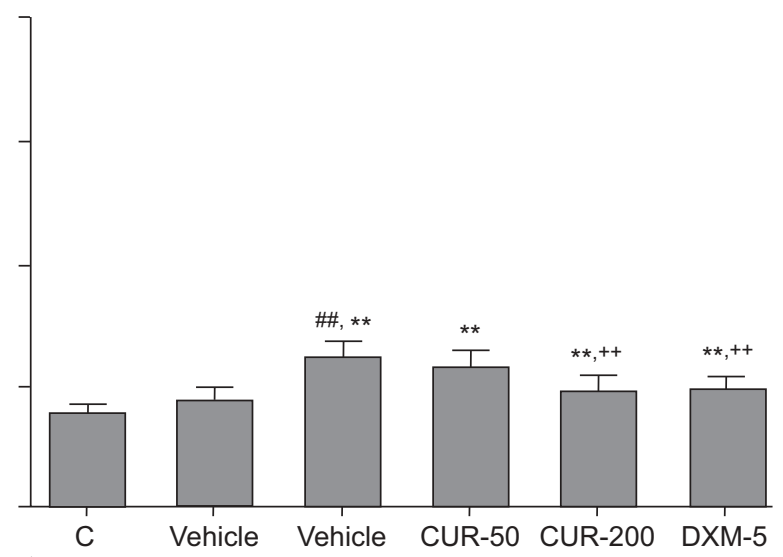

Pre-
treatment
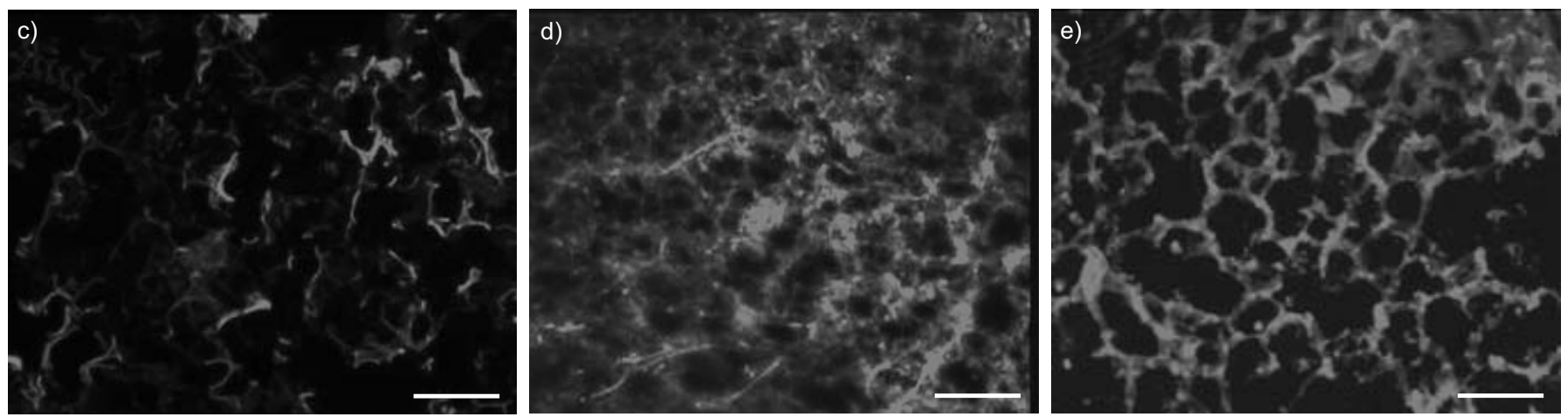

FIGURE 3. Assessment of lung microvascular permeability by quantification of Evans blue dye (EBD) in the parenchymal tissue of a) left lungs and b) right lungs. c-e) Spontaneous red fluorescence of EBD seen in lung tissue sections. c) No extravasation of EBD with a competent alveolar-capillary membrane was observed in animals undergoing sham operation and pre-treatment with vehicle. d) Obvious extravasation of EBD into the parenchyma was observed in ischaemia-perfusion-related acute lung injury (I/R-ALI) animals pre-treated with vehicle. e) Slight extravasation of EBD into the parenchyma was observed in I/R-ALI animals pre-treated with $200 \mathrm{mg} \cdot \mathrm{kg}^{-1} \mathrm{curcumin}^{-}$ (CUR-200). C: control; CUR-50: pre-treatment with $50 \mathrm{mg} \cdot \mathrm{kg}^{-1}$ curcumin; DXM-5: pre-treatment with $5 \mathrm{mg} \cdot \mathrm{kg}^{-1}$ dexamethasone; Sham: sham operation; I/R: ischaemiareperfusion. ${ }^{* *}: p<0.01$ versus sham operation group; ${ }^{\# \#}: p<0.01$ versus control group; ${ }^{++}: p<0.01$ versus I/R-ALI group pre-treated with vehicle. Scale bars $=50 \mu \mathrm{m}$. 
buffer was used for determinations of the enzymatic activities of xanthine oxidase (XO) [20], malondialdehyde (MDA) [21] and the total antioxidative capacity (TAOC) [22]. The activities of $\mathrm{MPO}, \mathrm{XO}$ and MDA, and TAOC in the lung tissue were determined using assay kits (Jiancheng Bioengineering Institute, Nanjing, China), according to the manufacturer's instructions.

\section{$N F-\kappa B, T N F-\alpha$ and IL-1 $\beta$ measurements}

To observe changes in NF- $\kappa \mathrm{B}$ activity, DNA binding activity was measured using an ELISA assay. Nuclear extracts of left lungs were prepared using the Nuclear Extract Kit (Active Motif, Carlsbad, CA, USA). P65 DNA binding activity was measured with $15 \mu \mathrm{g}$ of nuclear extract with the Trans-AM kit (Active Motif) according to the manufacturer's instructions [11]. TNF- $\alpha$ and IL- $1 \beta$ levels in left lungs and serum were determined using a rat TNF- $\alpha$ ELISA kit and IL-1 $\beta$ ELISA kit (R\&D Systems, Minneapolis, MN, USA), respectively, as described previously [23].

\section{Statistical analysis}

Results are presented as mean $\pm \mathrm{SD}$. Comparisons between multiple groups were performed by one-way ANOVA procedures, followed by Bonferroni's post hoc test for intergroup comparisons; in the case of unequal variances, a nonparametric Kruskal-Wallis test was performed. A p-value $<0.05$ was regarded as statistically significant.

\section{RESULTS}

\section{Histopathology and lung injury score}

Figure 1 shows the different degrees of I/R-ALI induced by the various treatments. Lung tissue oedemas in I/R-ALI animals pre-treated with vehicle or CUR at $50 \mathrm{mg} \cdot \mathrm{kg}^{-1}$ were more obvious than those in sham-operated animals (fig. 1), while pre-treatment with CUR at $200 \mathrm{mg} \cdot \mathrm{kg}^{-1}$ or DXM prevented from I/R-induced lung tissue oedema. The severity of ALI, characterised by lung tissue oedema, leukocyte infiltration and haemorrhage, was more obvious in I/R-ALI animals than in sham-operated animals, while CUR at $200 \mathrm{mg} \cdot \mathrm{kg}^{-1}$ and DXM had preventive effects, as seen morphologically in figure 1 .

\section{$A B G$ and lung wet/dry weight ratio}

Values of CA $\mathrm{Pa}_{\mathrm{a}} \mathrm{O}_{2} / \mathrm{FI}, \mathrm{O}_{2}$, LPV $\mathrm{Pa}_{1} \mathrm{O}_{2} / \mathrm{FI}_{1} \mathrm{O}_{2}$ (fig. 2a), left lung water content (fig. 2b) and right lung water content contralateral to the I/R side (fig. 2c) in all I/R-ALI animals were significantly lower or higher than those in sham and control animals $(\mathrm{p}<0.05$ and $\mathrm{p}<0.01$, respectively). However, pretreatment with CUR at $200 \mathrm{mg} \cdot \mathrm{kg}^{-1}$ or DXM significantly prevented I/R-induced changes of LPV $\mathrm{Pa}_{1} \mathrm{O}_{2} \quad(\mathrm{p}<0.05$ and $\mathrm{p}<0.01$, respectively; fig. $2 \mathrm{a}$ ) and left lung water content $(p<0.01$; fig. $2 b)$, compared with vehicle pre-treatment.

\section{Lung microvascular permeability}

A significant increase in EBD extravasation was found in $I / R$ left lungs of animals pre-treated with vehicle, CUR or DXM, as compared with sham and control animals $(\mathrm{p}<0.01$; fig. $3 a)$. Pre-treatment with CUR at $200 \mathrm{mg} \cdot \mathrm{kg}^{-1}$ or DXM significantly prevented I/R-induced increase in capillary barrier permeability, compared with vehicle $(\mathrm{p}<0.01)$. A similar pattern of inhibitory effects of CUR or DXM was also seen in the contralateral right lungs (fig. 3b).

\section{Lung tissue neutrophilic infiltration and oxidative stress}

Values of MPO activity (fig. 4a) and number of neutrophils (fig. 4b) in left lung tissue increased significantly in all animals with I/R-ALI compared with sham and control animals $(p<0.01)$, while pre-treatment with CUR at both 50 and $200 \mathrm{mg} \cdot \mathrm{kg}^{-1}$ or with DXM significantly prevented I/Rincreased MPO activity and neutrophil influx in lung tissue. As shown in table 1, tissue levels of MDA and XO increased significantly and tissue levels of TAOC decreased in I/R-ALI animals pre-treated with vehicle $(\mathrm{p}<0.01$ versus both control and sham animals). Both CUR at $200 \mathrm{mg} \cdot \mathrm{kg}^{-1}$ and DXM showed significantly inhibitory effects on I/R-increased tissue levels of MDA. However, only pre-treatment with CUR at $200 \mathrm{mg} \cdot \mathrm{kg}^{-1}$ had significantly inhibitory effects on I/Rincreased tissue levels of $\mathrm{XO}$ and I/R-decreased levels of TAOC, as compared with vehicle pre-treatment $(p<0.05$; table 1).

\section{NF- $\kappa B$ DNA binding activity and cytokine alterations}

$\mathrm{NF}-\kappa \mathrm{B}$ activity in lung tissue was significantly higher in all operated animals than in controls and in all I/R-ALI animals than in sham operation animals $(p<0.05$ and $p<0.01$, respectively; table 2). Pre-treatment with $200 \mathrm{mg} \cdot \mathrm{kg}^{-1} \mathrm{CUR}$ or with DXM significantly prevented I/R-induced NF- $\mathrm{BB}$ overactivation (by $64 \%$ and $76 \%$, respectively). Table 2 shows that tissue and serum levels of TNF- $\alpha$ and IL-1 $\beta$ increased significantly after induction of $\mathrm{I} / \mathrm{R}$, while $50 \mathrm{mg} \cdot \mathrm{kg}^{-1} \mathrm{CUR}$ showed significantly inhibitory effects on I/R-induced serum TNF- $\alpha$ and IL- $1 \beta$ and pre-treatment with CUR at $200 \mathrm{mg} \cdot \mathrm{kg}^{-1}$ or DXM significantly inhibited both lung tissue and serum TNF- $\alpha$ and IL-1 $\beta$.

\section{DISCUSSION}

The present study demonstrates protective effects of CUR similar to DXM on I/R-induced lung oedema, lung capillary endothelial barrier dysfunction, leukocyte infiltration, cytokine overproduction and tissue injury. The aim of using DXM in the present study was to evaluate the protective effects of CUR on I/R-ALI, with DXM used as an effective reference compound. However, it was found that only CUR could prevent I/Rincreased tissue levels of $\mathrm{XO}$ and I/R-decreased tissue levels of TAOC. This may indicate that CUR and DXM exert their antiinflammatory effects through different pathways. For example, it is possible that CUR might have more preventive effects on oxidative stress. An advantage of CUR is that oral doses of up to $8,000 \mathrm{mg} \cdot$ day $^{-1}$ appeared non-toxic to humans when taken for 3 months [24]. This suggests a potential use of CUR for long-term therapy for I/R-ALI. It was also noticed that left lung I/ $R$ caused an increase of capillary barrier permeability in the contralateral lung, which could be prevented by CUR or DXM pre-treatment.

MPO is an enzyme whose level of activity is known to be directly proportional to the number of neutrophils present [19] The present study demonstrated that I/R increased neutrophilic infiltration in lung tissue, as evidenced by both increased MPO activity and number of neutrophils in the tissue. CUR or DXM had anti-neutrophil influx effects. NF- $\kappa B$ is involved in the control of many genes in the early processes of immune and inflammatory responses [9], including the activation of a number of immune response proteins (e.g. TNF- $\alpha$, IL-1 $\beta$, IL-6 

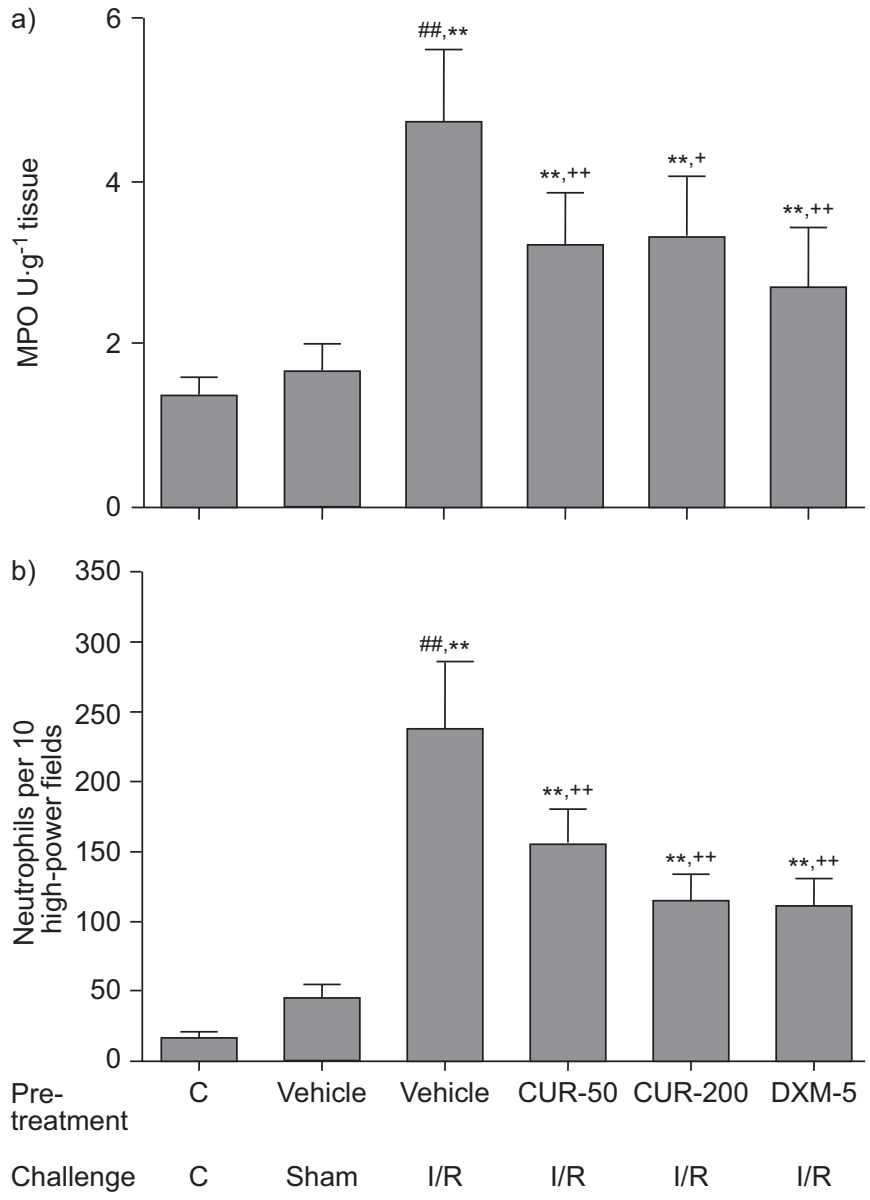

FIGURE 4. Neutrophilic infiltration assessed by a) lung myeloperoxidase (MPO) activity and $b$ ) number of neutrophils per 10 high-power fields of lung tissue. CUR-50: pre-treatment with $50 \mathrm{mg} \cdot \mathrm{kg}^{-1}$ curcumin; CUR-200: pre-treatment with $200 \mathrm{mg} \cdot \mathrm{kg}^{-1}$ curcumin; DXM-5: pre-treatment with $5 \mathrm{mg} \cdot \mathrm{kg}^{-1}$ dexamethasone; C: control; Sham: sham operation; I/R: ischaemia-reperfusion. ${ }^{* *}: p<0.01$ versus sham operation group; ${ }^{\# \#: ~} p<0.01$ versus control group; ${ }^{+}: p<0.05$ versus I/Rassociated acute lung injury (ALI) group pre-treated with vehicle; ${ }^{++}: p<0.01$ versus I/R-associated ALI group pre-treated with vehicle.

and IL-8). NF- $\kappa \mathrm{B}$ activation is tightly regulated by its endogenous inhibitor, inhibitor of $(\mathrm{I}) \kappa \mathrm{B}$, which complexes

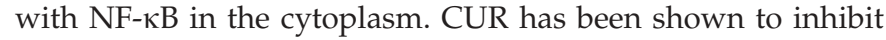
phosphorylation and proteolytic degradation of IKB and prevent the release and nuclear transmigration of NF- $\kappa B$ [25], similarly to DXM treatment, in cold-preserved alveolar epithelial cells [8]. The present study demonstrates I/Rinduced over-activation of NF- $\mathrm{KB}$ and hyperproduction of inflammatory cytokines both systemically and in local tissue.

Although both warm lung I/R and prolongation of the duration of cold transplantation partially present common pathological characteristics of I/R injury, lung transplantationassociated lung injury also includes graft rejection, injuries induced by lung flushing with organ preservation solution and complicated surgical manipulation. Cold preservation consumes less metabolic substrate than warm ischaemia, which could prolong the preservation time of the lungs. In addition, flushing with preservation solutions before cold storage could

\begin{tabular}{|c|c|c|c|}
\hline \multirow{2}{*}{$\begin{array}{l}\text { TABLE } 1 \\
\text { Group }\end{array}$} & \multicolumn{3}{|c|}{$\begin{array}{l}\text { Levels of xanthine oxidase }(\mathrm{XO}) \text {, malon- } \\
\text { dialdehyde (MDA) and total anti-oxidative } \\
\text { capacity (TAOC) in lungs after } 90 \text { min ischaemia } \\
\text { and } 4 \text { h reperfusion }\end{array}$} \\
\hline & $\begin{array}{l}\mathrm{XO} \mathbf{U} \cdot \mathrm{g}^{-1} \\
\text { protein }\end{array}$ & $\begin{array}{c}\text { MDA nmol } \cdot \mathrm{mg}^{-1} \\
\text { protein }\end{array}$ & $\begin{array}{c}\text { TAOC U } \cdot \mathrm{mg}^{-1} \\
\text { protein }\end{array}$ \\
\hline C & $9.31 \pm 1.32$ & $0.72 \pm 0.09$ & 3. $05 \pm 0.37$ \\
\hline Sham & $11.25 \pm 1.48$ & $0.79 \pm 0.12$ & $2.60 \pm 0.23$ \\
\hline Vehicle & $15.99 \pm 1.51^{\# \#, \star \star *}$ & $1.28 \pm 0.15^{\# \#, \star \star *}$ & $1.82 \pm 0.22^{\# \# \star \star}$ \\
\hline CUR-50 & $14.99 \pm 1.90^{\star \star}$ & $1.07 \pm 0.15^{\star \star}$ & $1.91 \pm 0.25^{\star \star}$ \\
\hline CUR-200 & $12.48 \pm 1.32^{+}$ & $0.90 \pm 0.06^{++}$ & $2.24 \pm 0.19^{+}$ \\
\hline DXM-5 & $13.36 \pm 1.95$ & $0.73 \pm 0.12^{++}$ & $2.08 \pm 0.28^{\star \star}$ \\
\hline
\end{tabular}

Data are presented as mean $\pm \mathrm{SD}$. C: control; Sham: animals undergoing sham operation and pre-treatment with vehicle; Vehicle: pre-treatment with vehicle; CUR-50: pre-treatment with $50 \mathrm{mg} \cdot \mathrm{kg}^{-1}$ curcumin; CUR-200: pre-treatment with $200 \mathrm{mg} \cdot \mathrm{kg}^{-1}$ curcumin; DXM-5: pre-treatment with $5 \mathrm{mg} \cdot \mathrm{kg}^{-1}$ dexamethasone. **: $p<0.01$ versus sham group; ${ }^{\# \#: ~} p<0.01$ versus control group; ${ }^{+}: p<0.05$ versus vehicle group; ${ }^{++}: p<0.01$ versus vehicle group.

alleviate the radicals and mediators of inflammation release after reperfusion to a greater extent than warm ischaemia. Furthermore, lung I/R can also exist in multiple pathophysiological conditions, e.g. shock, haemorrhage and trauma. Clinical and experimental studies have shown that I/R induces a rapid release of proinflammatory cytokines in the lung [3]. It is possible that ischaemia triggers the activation of donor macrophages, resulting in the release of proinflammatory cytokines and the development of I/R-ALI during the early phase of reperfusion [26]. That CUR or DXM could reduce levels of TNF- $\alpha$ and IL-1 $\beta$ after reperfusion indicates that they may inhibit activation of macrophages at the early phase of reperfusion. It seems that systemic levels of cytokines were more sensitive to CUR pre-treatment.

Oxidative stress plays an important part in experimentally induced reperfusion injury models [27] and IR-induced lung injury [28]. One important mechanism leading to the production of radicals is the accumulation of hypoxanthine and the conversion of the enzyme xanthine dehydrogenase into $\mathrm{XO}$ during anoxia, with the degradation of hypoxanthine into superoxide after reoxygenation [29]. XO-derived superoxide formation accounts for the major part of total superoxide produced during IR injury [27]. A recent study also showed that XO plays a prominent role in ALI because of its ability to generate radicals, such that activation of lung $\mathrm{XO}$ contributed to the development of capillary permeability related to ventilator-induced lung injury [30]. The current results and others [31] have demonstrated that CUR could prevent I/Rinduced $\mathrm{XO}$ over-activity, which indicates that CUR may directly prevent the production of superoxide during lung I/R. Thus, CUR has the potential to decrease oxidative stressinduced lipid peroxidation.

The balance between radical production and endogenous antioxidants is disturbed by increasing generation of radicals and reduced antioxidant defences during I/R of the lung, 


\begin{tabular}{|c|c|c|c|c|c|}
\hline TABLE 2 & $\begin{array}{l}\text { Levels of nuclear factor } \\
\text { serum (s) after } 90 \mathrm{~min}\end{array}$ & $\begin{array}{l}-\kappa \mathrm{B} \text { activities, tumour } \\
\text { emia and } 4 \mathrm{~h} \text { reperfu }\end{array}$ & sis factor (TNF) & ind interleukin (IL)-1] & lung tissue (t) and \\
\hline Groups & NF-кB OD & tTNF- $\alpha$ pg $\cdot \mathrm{mg}^{-1}$ protein & sTNF- $\alpha \mathrm{pg} \cdot \mathrm{mL}^{-1}$ & tIL-1 $\beta$ pg $\cdot \mathrm{mg}^{-1}$ protein & $\mathrm{slL}-1 \beta \mathrm{pg} \cdot \mathrm{mL}^{-1}$ \\
\hline C & $0.30 \pm 0.07$ & $4.71 \pm 0.79$ & $10.59 \pm 1.84$ & $15.89 \pm 3.25$ & $16.60 \pm 3.08$ \\
\hline Sham & $0.52 \pm 0.13^{\#}$ & $6.41 \pm 0.36$ & $13.14 \pm 1.76$ & $21.18 \pm 5.87$ & $20.87 \pm 3.64$ \\
\hline Vehicle & $1.68 \pm 0.15^{\# \#, \star \star}$ & $16.48 \pm 4.63^{\# \#, \star \star \star}$ & $41.28 \pm 8.32^{\# \#, \star * *}$ & $48.74 \pm 8.97^{\# \#, \star \star \star}$ & $59.08 \pm 10.59^{\# \#, \star \star *}$ \\
\hline CUR-200 & $1.11 \pm 0.17^{\star \star,++}$ & $10.70 \pm 2.58^{+}$ & $18.15 \pm 4.16^{++}$ & $35.76 \pm 6.38^{\star,+}$ & $24.37 \pm 3.39^{++}$ \\
\hline DXM-5 & $0.98 \pm 0.16^{\star \star,++}$ & $7.70 \pm 2.00^{++}$ & $16.17 \pm 3.95^{++}$ & $29.67 \pm 4.17^{++}$ & $25.21 \pm 4.42^{++}$ \\
\hline
\end{tabular}

resulting in severe oxidative stress, confirmed by a reduction in TAOC after I/R injury. Antioxidant treatment should reverse oxidative stress and the subsequent inflammatory effects through NF- $\mathrm{B}$ activation. The present study showed that CUR or DXM reduced the concentration of MDA during I/R, while only CUR showed preventive effects on I/Rinduced reduction of TAOC. The inhibitory effect of DXM on I/R-induced lipid peroxidation in the lung may result from anti-inflammatory activity rather than from direct antioxidant activity.

CUR is a major constituent of turmeric, while DXM is a synthetic drug. Their usage and dosage were both different in the present study. CUR is liposoluble and needed to be dissolved in DMSO. Although the present study showed preventive effects of both CUR and DXM, more attention should be paid to understanding the potential mechanisms by which CUR may be involved in the metabolism and balance of oxidative stress and antioxidants and to exploring clinical application of CUR for preventing oxidative stress. It should be investigated whether CUR has preventive and therapeutic effects on long-term lung I/R injury, organ dysfunction and the mortality rate of I/R-ALI.

In conclusion, the present study confirmed the protective effects of curcumin on ischaemia-reperfusion-induced lung inflammation, capillary barrier dysfunction, tissue oedema and injury, in a similar manner to the steroid dexamethasone. Curcumin reduces ischaemia-reperfusion-induced acute lung injury, probably through improvement of oxidative stress and nuclear factor- $\kappa \mathrm{B}$-mediated expression of inflammatory cytokines. Thus, curcumin may be an alternative therapeutic strategy for improving the outcome of ischaemia-reperfusioninduced lung injury.

\section{ACKNOWLEDGEMENTS}

The present authors gratefully thank D. Zhu (Zhongshan Hospital, Fudan University, Shanghai, China) and B. Sun (Children's Hospital, Fudan University) for providing technical and material assistance.

\section{REFERENCES}

1 King RC, Binns OA, Rodriguez F, et al. Reperfusion injury significantly impacts clinical outcome after pulmonary transplantation. Ann Thorac Surg 2000; 69: 1681-1685.

2 Hosenpud JD, Bennett LE, Keck BM, Boucek MM, Novick RJ. The registry of the International Society for Heart and Lung Transplantation: eighteenth official report - 2001. J Heart Lung Transplant 2001; 20: 805-815.

3 De Perrot M, Liu M, Waddell TK, Keshavjee S. Ischemiareperfusion-induced lung injury. Am J Respir Crit Care Med 2003; 167: 490-511.

4 Sakaguchi T, Sawa Y, Fukushima N, et al. A novel strategy of decoy transfection against nuclear factor- $\kappa \mathrm{B}$ in myocardial preservation. Ann Thorac Surg 2001; 71: 624-629.

5 Ross SD, Kron IL, Gangemi JJ, et al. Attenuation of lung reperfusion injury after transplantation using an inhibitor of nuclear factor-кB. Am J Physiol Lung Cell Mol Physiol 2000; 279: L528-L536.

6 Rahman I, Adcock IM. Oxidative stress and redox regulation of lung inflammation in COPD. Eur Respir J 2006; 28: 219-242.

$7 \mathrm{Xu}$ YX, Pindolia KR, Janakiraman N, Chapman RA, Gautam SC. Curcumin inhibits IL- $1 \alpha$ and TNF- $\alpha$ induction of AP-1 and NF- $\mathrm{BB}$ DNA binding activity in bone marrow stromal cells. Hematopathol Mol Hematol 1998; 11: 49-62.

8 Inoue K, Suzuki S, Kubo H, Ishida I, Ueda S, Kondo T. Effects of rewarming on nuclear factor- $\kappa \mathrm{B}$ and interleukin 8 expression in cold-preserved alveolar epithelial cells. Transplantation 2003; 76: 409-415.

9 Barnes PJ. Corticosteroid effects on cell signalling. Eur Respir J 2006; 27: 413-426.

10 Shoskes DA. Effect of bioflavonoids quercetin and curcumin on ischemic renal injury: a new class of renoprotective agents. Transplantation 1998; 66: 147-152.

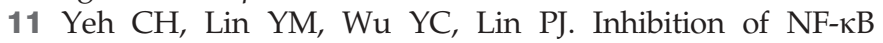
activation can attenuate ischemia/reperfusion-induced contractility impairment via decreasing cardiomyocytic proinflammatory gene up-regulation and matrix metalloproteinase expression. J Cardiovasc Pharmacol 2005; 45: 301-309.

12 Hafezi-Moghadam A, Simoncini T, Yang Z, et al. Acute cardiovascular protective effects of corticosteroids are 
mediated by non-transcriptional activation of endothelial nitric oxide synthase. Nat Med 2002; 8: 473-479.

13 Vieira AT, Pinho V, Lepsch LB, et al. Mechanisms of the anti-inflammatory effects of the natural secosteroids physalins in a model of intestinal ischaemia and reperfusion injury. Br J Pharmacol 2005; 146: 244-251.

14 Ghoneim AI, Abdel-Naim AB, Khalifa AE, El-Denshary ES. Protective effects of curcumin against ischaemia/reperfusion insult in rat forebrain. Pharmacol Res 2002; 46: 273-279.

15 Institute of Laboratory Animal Research. Commission on Life Sciences, National Research Council. Guide for the Care and Use of Laboratory Animals. Washington, National Academies Press, 1996.

16 Farivar AS, Krishnadasan B, Naidu BV, Woolley SM, Verrier ED, Mulligan MS. Alpha chemokines regulate direct lung ischemia-reperfusion injury. J Heart Lung Transplant 2004; 23: 585-591.

17 Okada M, Yamashita C, Okada M, Okada K. Contribution of endothelin-1 to warm ischemia/reperfusion injury of the rat lung. Am J Respir Crit Care Med 1995; 152: 2105-2110.

18 Sun J, Guo W, Ben Y, et al. Preventive effects of curcumin and dexamethasone on lung transplantation-associated lung injury in rats. Crit Care Med 2008; 36: 1205-1213.

19 Krawisz JE, Sharon P, Stenson WF. Quantitative assay for acute intestinal inflammation based on myeloperoxidase activity. Assessment of inflammation in rat and hamster models. Gastroenterology 1984; 87: 1344-1350.

20 Brunschede H, Krooth RS. Studies on the xanthine oxidase activity of mammalian cells. Biochem Genet 1973; 8: 341-350.

21 Draper HH, Hadley M. Malondialdehyde determination as index of lipid peroxidation. Methods Enzymol 1990; 186: 421-431.

22 Wang CB, Yao RY, Liu ZT, Zhong WZ, Liu XP, Wang YJ. Protective effect of polypeptide from Chlamys farreri on hairless mice damaged by ultraviolet A. Acta Pharmacologica Sinica 2002; 23: 813-818.

$23 \mathrm{Su}$ CF, Liu DD, Kao SJ, Chen HI. Nicotinamide abrogates acute lung injury caused by ischaemia/reperfusion. Eur Respir J 2007; 30: 199-204.

24 Cheng AL, Hsu CH, Lin JK, et al. Phase I clinical trial of curcumin, a chemopreventive agent, in patients with highrisk or pre-malignant lesions. Anticancer Res 2001; 21: 2895-2900.

25 Jobin C, Bradham CA, Russo MP, et al. Curcumin blocks cytokine-mediated NF- $\kappa \mathrm{B}$ activation and proinflammatory gene expression by inhibiting inhibitory factor I-אB kinase activity. J Immunol 1999; 163: 34743483.

26 Eppinger MJ, Jones ML, Deeb GM, Bolling SF, Ward PA. Pattern of injury and the role of neutrophils in reperfusion injury of rat lung. J Surg Res 1995; 58: 713-718.

27 McCord JM. Oxygen-derived free radicals in postischemic tissue injury. New Engl J Med 1985; 312: 159-163.

28 Jurmann MJ, Dammenhayn L, Schaefers HJ, Haverich A. Pulmonary reperfusion injury: evidence for oxygenderived free radical mediated damage and effects of different free radical scavengers. Eur J Cardiothorac Surg 1990; 4: 665-670.

29 Kelly RF. Current strategies in lung preservation. J Lab Clin Med 2000; 136: 427-440.

30 Abdulnour RE, Peng X, Finigan JH, et al. Mechanical stress activates xanthine oxidoreductase through MAP kinasedependent pathways. Am J Physiol Lung Cell Mol Physiol 2006; 291: L345-L353.

31 Lin JK, Shih CA. Inhibitory effect of curcumin on xanthine dehydrogenase/oxidase induced by phorbol-12-myristate13-acetate in NIH3T3 cells. Carcinogenesis 1994; 15: 1717-1721. 